\title{
REICE
}

Revista Electrónica de Investigación en Ciencias Económicas

Abriendo Camino al Conocimiento

Facultad de Ciencias Económicas, UNAN-Managua

Vol. 8, No. 16, Julio - Diciembre 2020

REICE ISSN: 2308-782X

http://revistacienciaseconomicas.unan.edu.ni/index.php/REICE

revistacienciaseconomicas@gmail.com

REICE

\section{Information Technologies and Reaching to Information Society}

Tecnologías de la información y llegar a la sociedad de la información

Fecha recepción: julio 02 del 2020

Fecha aceptación: septiembre 29 del 2020

Mehmet Nesip Öğün

University of Mediterranean Karpasia, North Cyprus

Email: mehmet.ogun@akun.edu.tr

ORCID: https://orcid.org/0000-0002-5866-1341

Behcet ÖZNACAR

Near East University, North Cyprus

Email: behcet.oznacar@neu.edu.tr

ORCID: https://orcid.org/0000-0002-6738-645X

Ali TATAR

University of Mediterranean Karpasia, North Cyprus

Email: ali.tatar@akun.edu.tr

ORCID: https://orcid.org/0000-0001-9832-8108

Gülyüz DEBEŞ

University of Mediterranean Karpasia, North Cyprus

Email:gulyuz.debes@akun.edu.tr

ORCID: https://orcid.org/0000-0003-3931-4501

DOI 10.5377/reice.v8i16.10708

(c) (i) (2)(2)

Derechos de autor 2020 REICE: Revista Electrónica de Investigación en Ciencias Económicas. Esta obra está bajo licencia internacional CreativeCommons Reconocimiento-NoComercial-Compartirlgual 4.0. Copyright (c) Revista Electrónica de Investigación en Ciencias Económicas de la Unan- Managua 


\begin{abstract}
.
The quick development of information and communication technologies has made the countries using these technologies a step forward in the global competition. Thanks to the contributions of the public, private sector and non-governmental organizations all over the world since the beginning of the 1990s, there has been considerable progress in reaching the information society. The age we live in is called the information age. In this society where knowledge becomes power, a lot is expected from individuals. There is a need for individuals who can reach the information themselves, question the information they obtain, use them in line with their needs, and have the ability to think scientifically. In this study, analysis of written documents was used. In this respect, the analysis of written documents and documents is an information gathering method used in the qualitative research to support the information obtained both on its own and the interview and observation.
\end{abstract}

keywords: Information, Technology, Knowledge Management, Information Society.

\title{
Resumen
}

El rápido desarrollo de las tecnologías de la información y la comunicación ha hecho que los países que utilizan estas tecnologías sean un paso adelante en la competencia mundial. Gracias a las contribuciones de las organizaciones públicas, privadas y no gubernamentales de todo el mundo desde principios de los años noventa, se ha avanzado considerablemente en llegar a la sociedad de la información. La edad en la que vivimos se llama la era de la información. En esta sociedad donde el conocimiento se convierte en poder, se espera mucho de los individuos. Es necesario que las personas puedan acceder a la información por sí mismas, cuestionar la información que obtienen, usarla de acuerdo con sus necesidades y tener la capacidad de pensar científicamente. En este estudio, se utilizó el análisis de documentos escritos. A este respecto, el análisis de documentos escritos y documentos es un método de recopilación de información utilizado en la investigación cualitativa para respaldar la información obtenida tanto por sí misma como para la entrevista y la observación.

Palabras clave: Información, Tecnología, Gestión del Conocimiento, Sociedad de la Información. 


\section{Introduction}

While the historical background of knowledge is a force that societies create in accordance with the need, today, it focuses on using information. Fast evolving and changing living

standards caused societies to enter economic competition, in this process the production, REICE | 414 use and sharing of knowledge started to increase from the mid-20th century (Yıldırım, 2010: 1313). At a time when globalization is gaining momentum, technological developments affect many business practices. Especially in the last decade, the speed of development in computer technology has left other technological developments in the shade. Through the increasing development of information technologies, an information and communication network has been built around the world. This global communication network has been the main source of information for scientific research, productivity, cultural change, global trade and global education. This network constitutes a global center for writing, verbal and video communication among all people living in the world. Continuously developing computer technology, as in every other subject, has found very important applications in management science. Nowadays, organizations make the records of the organization, information and changes about these records with the help of computers. Nowadays, when the competition is very intense, it is of great importance that the data of the organization and the results of the personnel analysis are sent to the management level quickly and reliably. The need for fast and accurate decision-making by managers in terms of maintaining their assets is an indicator of how computers play an important role in the field of management information system. According to Barnatt (1996:1), many businesses cannot do any work without computer systems. While many businesses and other organizations rely on information technology to improve their efficiency and efficiency, information technologies play an important role in the success of many critical tasks. Thus, the impact of information technologies in industrialized societies is observed in almost all business processes and functions (Gunasekaran and McGaughey, 2001:1).

The information produced after the production of the information needs to be shared to be used. These sharing activities involve the transmission of the information produced by 
individuals and groups through social networks (Sagsan, 2014: 32-33). When the information is used, it is seen that information is always used as a power.

According to information needs, the definition extends from Socrates to the present day. The information was first applied to the tool, process and product depending on the time of use, and this gave rise to the Industrial revolution. During the Second World War, the purpose of the use of knowledge has changed, and after this war, knowledge has been in front of the capital and labour factor (Güçlü and Sotirofski, 2006: 352-353).

Today, it can be said that the production and sharing of knowledge is one of the most important elements on the way to the information society. It can be said that the production and sharing of information is critical for maintaining sustainability and competitiveness both socially and organizationally. This study uses qualitative research technique to examine how information technology effects management in the organizations as well as usage of knowledge management.

\section{Materials and methods}

This is a descriptive research based on sources and data in existing documents and research. Therfore, in this study, analysis of written documents was used. In this respect, the analysis of written documents and documents is an information gathering method used in the qualitative research to support the information obtained both on its own and the interview and observation.

\section{Analysis and Results}

The strategic knowledge that the organization has in increasing and sustaining competitiveness is extremely important. If an organization has strategic knowledge of how unique and valuable it is, the organization has a potential strategic advantage. If the strategic knowledge needs to be up to date in a dynamic competition environment, the learning capacity of the organization should be sufficient. For these reasons (Aktan, 
1998:9); the aim of knowledge management is to provide a learning organization in order to obtain and continue to produce the strategic knowledge that includes the features such as original, useful, valuable, conservable, dynamic, and learning abilities. With the information age, the importance of the concept of knowledge has increased day by day. The competitive advantage of the companies that are aware of the knowledge has increased. In this competitive environment, being aware of the knowledge is not enough for the firms and it has become obligatory to consider information as a management approach. The main purpose of knowledge management is to sustain the sustainability of the activities of organizations and organizations, to deal effectively with the problems that may arise. In this context it aims to organize and disseminate knowledge within the institution in the best way and to organize its protection.

The most important source of knowledge is man, and this point it can be said to be the best move by making the person a focal point. Knowledge management is a very important factor to provide competitive advantage and aims to ensure that the information sources available are met in the optimum solution.

\section{Definition of Knowledge Management}

Since humanity has existed, humanity has had its own social and economic stages. These are primitive society, agricultural society, industrial society and information society. Today, while most of the societies live in the stages of agriculture, industry and advanced industry, it is known that those who dominate based on globalization are at the stage of information society (Koza, 2008). In the first societies, people were intertwined with nature and realized their learning through trial and error. With the formation of the agricultural society, they discovered the cultivation of the land and, as a result, established small villages by initiating life in agriculture. In the following years, with the invention of steam engines in the search for innovation, they formed the beginning of the industrial revolution and with the industrial revolution, basic capital, machinery and industry have been (Ender, 2004). In today's competitive environment, it is inevitable to care about information and to see it as added value. It is seen that the firms, which have a power in the competition, have survived and other companies stumbled across this road. With the actions such as the 
acquisition, use and storage of knowledge, the concept of managing knowledge has gained importance. Managing knowledge has become a necessity rather than an action. The reasons that require knowledge management (Çetin, 2003);

- The continuation of mental capital within the organization is developing as the most decisive requirement for information management systems.

- Developments in information technology,

- Developments in communication technology,

- New, integrated economy,

- The quality of its customers and expectations has made knowledge management a priority to be considered in terms of organizations.

In the case of successful implementation of knowledge management, researchers have achieved results that positively affect the performance and creativity of the organization and that the firms increase their competitiveness significantly (McKeen ve Singh, 2009; Liao ve $\mathrm{Wu}$, 2009). Knowledge management is not just a management approach but an understanding that changes the corporate culture.

With the knowledge management, both the management approach and the corporate culture have changed. Knowledge management increases the tendency of the institution to innovation and technology. It changes the atmosphere of the institution. Knowledge management has some distinctive features and companies that adopt knowledge management have adopted these features. Characteristics of knowledge management Çapar (2002):

- Makes knowledge in the institution productive. Ensuring the most efficient use of intellectual capital within the institution,

- Provides knowledge to be produced, stored, transferred, accessed, used. Combining knowledge and communication technologies and people's creativity, provides fast and accurate solutions to the problems of the institution,

- Knowledge management is interdisciplinary. It is an interdisciplinary activity that takes advantage of the fields of information, communication technology, communication, new economy, information science, business, finance, psychology, sociology, linguistics, engineering, 
- It is based on knowledge management, cooperation, information sharing and using each other's ideas and ensures that this culture develops within the organization,

- Knowledge management is a continuous application and specific to the organization,

- Knowledge management is based on leadership, order, learning, technology, support for

corporate transactions, dissemination of information according to person and unit, sharing and sharing of information, revealing implicit information as part of the working process, measurement of information existence, creation of corporate knowledge culture and information technology,

- Prevents the disclosure of important and critical knowledge for the institution by providing the disclosure of closed knowledge.

- Prevents information from going out of the organization.

In this respect, knowledge management is the concept of the environment, including systems, processes, and culture, and is the tool for capturing and sharing existing knowledge along with the creation of new knowledge (Firestone, 2005). Knowledge management is a new essential way to create, retain, share and improve information for the realization of organizational goals (Barutçugil, 2009). The purpose of knowledge management is to increase the ability of the enterprise to create value by providing more efficient use of information. In other words, in order to achieve the highest efficiency in accordance with the objectives of the organization, the most effective way is to use the intellectual capital and knowledge assets of the organization.

\section{Knowledge Hierarchy}

In our daily life, we are subject to intense information interaction from the written and visual media and the people we communicate with. Very few of these information concerns us. Man receives records and uses information that concerns him / herself. When it creates value for human beings, information becomes knowledge. The fact that man is happy in modern life is realized by meeting all his needs. Since knowledge is an important tool of material spiritual happiness, its value is understood more and more every day and information is used in all areas of social life and draws attention due to its value.

The information that is in a development since the day of human existence has been subject to different definitions in different periods of history. However, its underlying 
meaning has always remained the same. The meaning and the elements that make up it are determined according to the needs analysis of the day. The information comes from the Latin word informatio. It is defined as the act of formatting. In time, the concept of knowledge has been defined and explained in different ways. As the concept of knowledge begins to be understood, it has become a very important concept for the institutions and has taken its place as a factor controlling the whole process.

Knowledge, with the shortest definition of the data is known as the processed state. In other words, knowledge is the meaning of the important data in the human brain to make a result. In defining the knowledge, many factors are gathered together. Data, mind, interpretation, memory, process words are concepts that help to create knowledge. Information has become an inevitable resource especially in the recent days when competitive advantage comes into prominence. The acquisition, efficient use, sharing and making it a power has become an agenda. Information, companies want to come to the point where they want to arrive at the shortest time and cost, while looking for ways to stay one step ahead of other companies has been a factor that can shed light on this path. The institutions that have understood the importance of information want to expand their e-business activities to the field of knowledge in order to provide control and management of their information assets. The field of knowledge is not only about access to this information, but also about what rules can be reached and how to classify this information. A company that is aware of this field of knowledge and makes this field manageable gains a significant advantage against its competitors by moving its work into an e-business environment. A company that develops applications at this level is now at the highest level of e-business maturity. This will only be possible by understanding the importance of information. Knowledge has an increasing importance in terms of providing competitive advantage. Institutions that are aware of this situation are moving faster in the way of institutionalization.

The most common paradigm in the knowledge management literature is the hierarchy of information shown in Figure 1 (Davenport and Prusak, 1998). The hierarchy of information shows the concept of traditional information transformations in which data is transformed into information. 


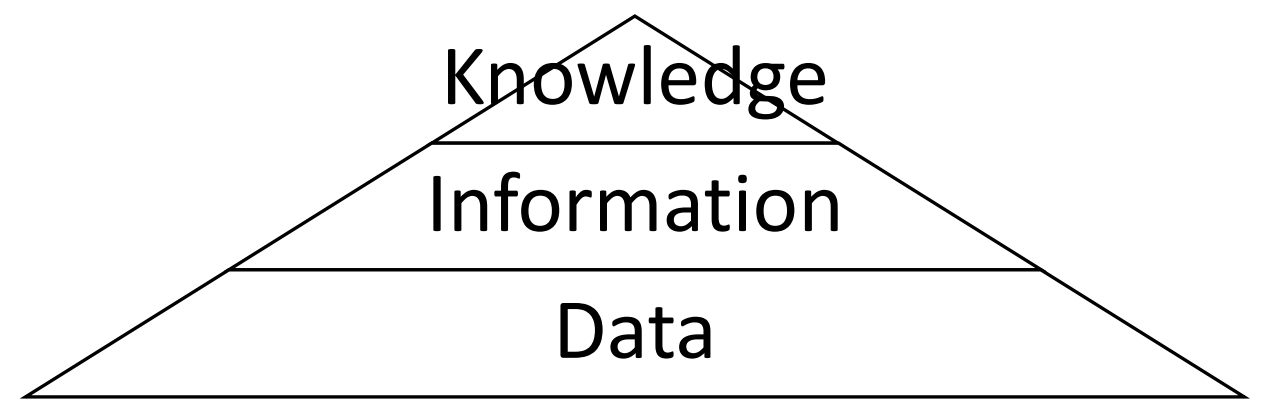

Figure 1. Knowledge Hierarchy by Davenport and Prusak (1998)

Knowledge has become a critical driving force for business success and value creation (King and Zeithalm, 2003). Many firms explore the knowledge management area to develop and maintain their competitive advantages and see information management as a critical resource. Knowledge management seeks to make tactical knowledge and experience more accessible to improve the efficiency and effectiveness of institutions. As knowledge management has become a notable issue in recent years, businesses are focused on raising and capturing information.

Data, information, knowledge, Wisdom (DIKW) hierarchy (see Figure 2), also known as information hierarchy, information hierarchy and information pyramid, forms the basis of information systems research (Rowley, 2007, p. 163).

While the hierarchy itself is often quoted and applied explicitly or indirectly in the information systems literature, the direct discussion of the content and structure of the hierarchy has been limited (Zins, 2011). In particular, the concept of wisdom has received very limited discussion in the literature (Rowley, 2007).

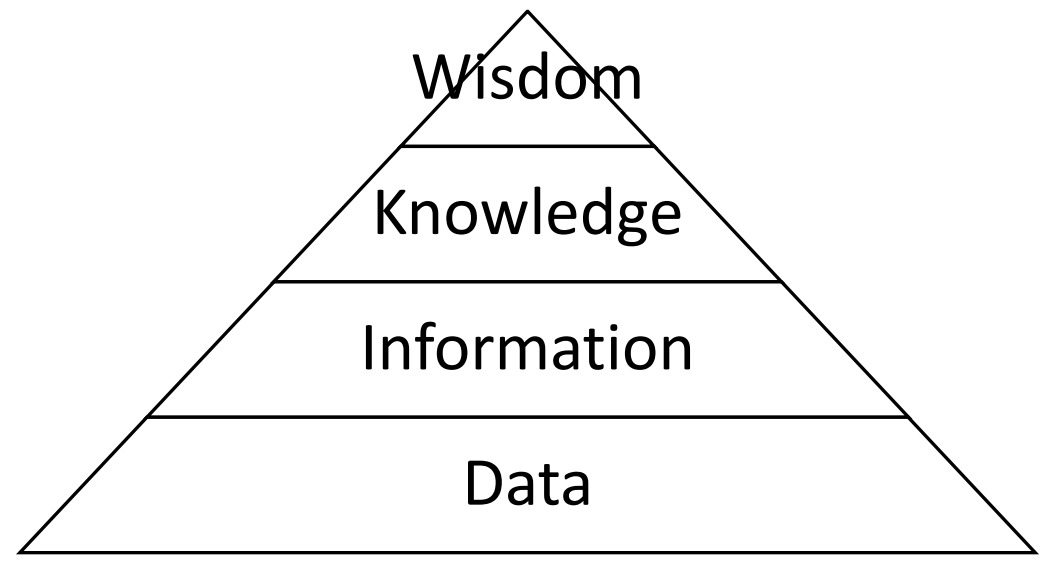


Figure 2. Knowledge Hierarchy by Rowley (2007:163)

Wisdom is the ability to increase effectiveness. Intelligence is the ability to increase productivity. Knowledge is what makes it possible to convert the information into instructions. Information provides answers to questions of who, where, where and when. The data is defined as symbols representing the properties of objects, events, and surroundings. They are the products of observation (Rowley, 2007, p. 166). Variations of this central theme include Tuomi (1999), which suggests an inverted hierarchy. Its position is that information must represent the information needed to store the data. Nissen (2000) extends this concept with a model with two hierarchies. A hierarchy models the view of the information seeker, in which the second hierarchy is reversed and represents the opinion of the knowledge creator.

An extension to the information hierarchy is expressed by Ackoff (1996), describing the data as symbols, information that is processed to be useful, information as a data application, and information to answer " how " questions, understanding the ability to answer " Why " and as an understanding of knowledge. Instead of the hierarchy, Kakabadse et al. (2003) regards data, information, realization, action and wisdom as an flow chain of information. Implementation refers to information that is given to productive use. Action / reflection is reflective and integrative, and is a desire to act. Through action / reflection, one can gain wisdom. Because understanding and wisdom are unlikely to have computers (Ackoff, 1996), we see them as the dimensions of personal knowledge.

The hierarchy of information can be used to estimate the mobility and volume of each layer in the hierarchy. Knowledge is the most mobile, but the rarest is the point where the data is the least transactionable but at the highest volume (Nissen, 2000).

Despite the model's objections to data, information, knowledge and wisdom of a variety of different types, this hierarchical and pyramidal model provides useful information not only for staff and organization management, but also for the organization of library resources. By providing a model of ontology and the structure of knowledge, it has become canonical for knowledge organization. 


\section{Data}

Data is a set of symbols, characters, letters, numbers and signs that are collected from different sensors and do not mean anything of their own. Data are objective facts of events and not related to each other. These objective facts do not make sense on their own.

Therefore, data cannot be established alone and the goals cannot be reached. In line with the theory of knowledge (Shannon, 1948), the data are defined as knowledge of thermodynamic (physical) entropy (Boisot and Canals, 2004). Per se, data can be considered as designs with no meaning, information as understood data and knowledge as "information incorporated in an agent's cognitive resources" (Aamodt and Nygård, 1995:196).

For the enterprises, the definition of the data is the most important records of the transactions. In modern organizations, data is stored in technological systems. Since the speed and capacity of using these data is of great importance for companies, data management creates a separate specialty branch and companies allocate large amounts of resources to data storage and systems to find and make available these data any time. Having a lot of data and collecting a lot of data is not always an indication of making the right decisions. It is difficult, costly and time-consuming to pick up a lot of data and choose from them. Because they do not make sense on their own, they are not a trust in decision-making. Transformation of data into information follows these steps; collection, organizing, summarizing, analyzing, synthesizing and decision-making. Before taking action, it is necessary to summarize, analyze and synthesize the information together with the collection and organization of the data. During this process, raw data is associated with the situation and context in which it is produced (Honey et al., 2005).

\section{Information}

Information can be defined as organized, structured, interpreted, summarized data. The regulation was made by others and only meant for the person concerned. Information, which has a much richer content than data, is a written, verbal or visual message. As in each message, information must be a sender and a recipient for the transmission of the 
information. The information is intended to influence the perception or change of the perception of the person receiving the message (Barutçugil, 2002).

Information (Davenport and Laurence, 2001) can also be defined as a visual or audio message or message in the form of a document. The purpose of the information is to change the views of the buyer on a subject, to evaluate or to influence his / her behaviour. It should make a difference in its perspective or understanding by shaping the information receiver

\section{Knowledge}

Knowledge, clearly or at least implicitly, requires judgment. In other words, knowledge does not come from a simple grasp of an object or from an understanding of an existing object. In knowledge, the cognition or comprehension constitutes a first step. According to this, it can be said that the subject knows when he makes comparisons, makes distinctions, establishes connections and makes determinations (Cevizli, 2010:14). Knowledge is the inferences generated from the associated sets of associated, unified and conceptualized information.

Knowledge is what can be judged about those whose existence is accepted. Existing things can be material and spiritual beings. The material ones can be real and virtual among themselves. Truth is the one that exists outside the mind. Virtual is the non-existent existence outside the mind. However, from an epistemological perspective, philosophers and scientists have been struggling with the definition of knowledge for thousands of years (Alavi and Leidner, 2001).

Similarly, knowledge management that emerged in think tanks and management schools in the United States (Shields, 2001) has not been clearly identified (Zhao et al., 2012) or differentiated from relevant research areas (Gray and Meister, 2003). On the other hand, in the light of the constructivist knowledge theory (Piaget, 1977), it was claimed that knowledge is subjective and made from personal interpretations (Martin et al., 2009). Therefore, a common view is that knowledge is the product of a synthesis of the mind of the person who knows (Leonardi and Treem, 2012) and only exists in his mind (Zins, 2011, Galliers and Newell, 2001) Given that knowledge always includes a person who 
knows (McDermott, 1999), it can be said that all knowledge is tacit and that what can be materialized and embodied outside the human mind is only information (Stenmark, 2002:928). For example, a library or computer may contain too much information, but does not contain knowledge (McDermott, 1999). The specific characteristics of the information are as follows (Allee, 1997:71):

- Knowledge is complicated.

- Knowledge is self-organization.

- Knowledge requires community.

- Knowledge moves through language.

- The longer the information is kept, the sooner he disappears.

- Knowledge, the more common, the better.

- There is no single solution.

- Knowledge does not develop forever.

- Knowledge does not belong to a single person.

- No system can be imposed.

- There is no magic way for knowledge.

- How knowledge is defined determines how it is managed

Knowledge is created and shared by individual and common minds. For this reason, it is learned by experience with success and failure audits not obtained from databases (Tiwana, 2003). Knowledge, in a more specific case, can be defined as valued information. In this context, it will be useful to mention the content difference between knowledge and information. Knowledge arises from the use of information in connection with a specific purpose. Knowledge is information enriched by interpretation, interpretation and context (Yeniçeri, 2005).

\section{Information Technologies}

Societies have always been subject to a change and development from the first formations to the present day. This change and development and the new information has been passed on through generations. In recent history, these changes, which started with the Renaissance movement, gave birth to the Industrial Revolution in the 18th century. The 
war industry has developed in line with the new quests and expectations of the countries, especially after the Second World War, countries have begun to show developments in science and technology. Societies have always needed a power from the ancient times to the present. Muscle power is at the forefront in the industrial society, and after the Second World War, muscle strength has been replaced by brain power. The workers who work with muscle power have been replaced with knowledge workers and the tools and equipment used have changed and improved.

As a result of the power created by the technology used in World War II, societies adopted knowledge as a force and as a result of this, as a result of the information society that gave rise to the information society in the 1950s, computer technologies were used. An information age has been formed that has been left behind by the industrial revolution and computer technology, in which raw material is used effectively and information is used (Ünal, 2009: 124-125). It is seen that the first 40-50 years of the computers in the process of reaching the technological level of examining the first phase of the calculations are seen as supporting machines. From the 1970 s to the 1980s, the process of transition to the information society was experienced as a result of the increasing difference between the account values of the organizations and the market account values. Especially in the 1990s, the search for raw materials, which will enable organizations and societies to be more economically advanced, and bring them to the level of welfare, has left organizations to leave material assets behind and give importance to intangible assets, in other words information (Akyüz, 2005: 41-42).

In the century we live, the most important power is knowledge. Information technologies are the most effective and easy way to reach information. The most important feature of the individuals who can keep up with the age is accessing qualified information and using the information. At this point, the most important problem is how to obtain, distribute and store information. This is the main reason for the rapid development of information technologies. Information technologies are indispensable both to maximize the level of information and to adapt to the ever-changing conditions of the information age.

In order to provide the necessary information in the decision-making process, the computer-aided information system that collects, stores, processes and reports data from 
various sources is called information systems. Like all systems, information systems are made up of interconnected parts. The content of computer systems; When creating inputs, processes, data files and printouts, they are executed and controlled by hardware and personnel (Hicks, 1993).

Information technology, telephones (computers, scanners, digital cameras, etc.) and computer software (database and multimedia programs), telephones, document-passes, modems it is a term used to describe telecommunication tools that enable and access information such as computers. Information technologies are connected and interactive technologies that include computer and communication technologies (hardware), methods to convert data to useful headers and metadata in terms of management (Ögüt 2001).

Information technologies can be defined as technologies that collect the information, process, store and transmit it to any place where it is needed or access it from anywhere (Ceyhun and Çağlayan 1997). Quickly produced information can be delivered to a large number of people in every area (business, economy, education, etc.) via IT.

Developed countries are always one step ahead of the time in which individuals are valuable, time can access information and use knowledge correctly. For this reason, it is necessary to determine the requirements in the field of information technologies in a good way, to develop the right solutions, to be able to implement the solutions well and to have the right strategy. In order to educate individuals who can think critically, to make decisions, to think creatively, to solve problems, to educate individuals who are open to innovations that can use computer programs, IT technologies are needed.

Information technologies are systems created by using computer and communication technologies together. Information technologies; In addition to micro-electronic and data transmission, they are technologies that include fax machines, mobile phones, cable television, computers, information networks, videotex, software and on-line databases. In organizational correspondence, data obtained with the help of information technologies are collected, classified, recorded and processed in a way to be converted into information and used in decision processes. 
Today, it is possible to think about communication and computer technologies together. The rapid development of computer and communication technology accelerated and facilitated the flow of information for the production and increased the efficiency and efficiency in production with the advantages it provided in the use of time.

Information and communication technologies that provide communication in management are developing rapidly. Video recorders, tele-secretary devices, closed-circuit television systems, fax machines, new communication flexibility in management. The most important benefit of communication technology is that it provides great convenience to written communication.

\section{Internet, Information and Communication Technology}

The Internet is a world-wide and ever-growing network that connects many computer systems with the TCP / IP protocol. The Internet is the most valid way to reach and share information easily, cheaply, quickly and securely. In 1969, the Ministry of Defense began to design a packet-switched network called ARPANET (Advanced Research Projects Agency Network) to support various computer and military research projects.

According to the project, any computer failure would not affect other networked computers and communication would continue. Since there was no center to regulate or control the network, a continuous and continuous communication would be possible. This project, which is the basis of today's Internet, increased the number of new computers by adding new computers to the same network and new usage areas such as electronic letters, discussion lists, forums and file transfer services were used by many users.

For scientific purposes other than ARPANET, NSFNET (National Science Foundation) In 1986, new networks such as Compuserve for commercial purposes were introduced. In 1973 , it was decided that different networks would be able to transmit data between them and create a common language.

For this purpose, TCP / IP (Transmission Control Protocol / Internet Protocol) was introduced. TCP / IP has been developed as a common language that enables different computers and networks on the Internet to communicate with each other in a healthy way. The last step in the development of the Internet is the development of the World Wide 
Web. The WWW has fulfilled an important function with the ease of Internet usage and user increase.

If it is needed to be classified communication and collaboration technologies used in information management and sharing, they are; communication and collaboration technologies, information main gates (portals), Intranets and Extranets. Communication and collaboration technologies enable individuals to use information and communication technologies to communicate information. The main gates of information are structures that provide access to many sources of information from a single point. Intranets are places where people who work within the organization reach and share information, and in-house information management is done. The full use of enhancements in the hardware field that express the physical parts that make up the computer has also developed the software space, expressed as commands that drive and direct hardware activities.

There are two major developments in the field of software for the user. The first is the choice of ready-made software packages from software vendors rather than by professional programmers or special programs developed by users of an organization. This trend is accelerated by the development of inexpensive and easy-to-use software packages for microcomputers, while for mini and host users, the development continues. Second, from procedural languages using technique, machine-specific programming, idioms or mathematical explanations based on binary or symbolic coding, human, it is closer to the non-procedural (fourth) natural languages. This trend gained momentum with the development of easy non-procedural fourth-generation languages. Developments in the field of artificial intelligence, which create natural language and graphical user interfaces that make the use of software packages easier, continue this trend.

As previously stated, there have been rapid developments in computer and communication technology over time. It is understood that the developments are not completed and will continue at the point reached today. The two main drivers of this change in IT technologies are the rapid emergence of new technologies and the demand of business environments for the support of information technologies. In a global competitive environment, enterprises need the support of information technologies with different goals and expectations. In this context, it is important to understand the strategic advantages that information technologies offer to organizations, to use knowledge in 
making the right decision and to be the most important factor in reducing uncertainty about the future (Mutsaers et all, 1998).

Communication technology and computers, along with the improvements in communication channels and message transmission, began to integrate in the 1960s and networks that enabled communication between computers emerged. At this point, the development of communication technologies in general; The journey which started with the invention of the telegraph in 1837, continued with the phone in 1875 and the invention of telex in 1927. The development of computers and transistors in the 1950s was followed by modern in the 1960s. In the 1970s, it was introduced with the first data networks and the electronic data change was used in the transportation sector. After the 1980 s, valueadded networks have emerged, and a rapid growth has been observed among organizations. One of the most important developments in communication technology has been the introduction of the internet for the military and academic purposes with the public offering (Pawar and Driva, 2001).

The development of computer technology from ENIAC, which is the first operational electronic numerical computer which was developed in 1946, is being examined in 5 pillars. Developments in the computer equipment, starting with vacuum tubes and transistor technology, have accelerated by the use of semiconductor technology since the third cycle. From the cumbersome, slow and short-lived vacuum tube technology that created the first cycle, we have reached the fifth phase where artificial intelligence, expert systems and complex mathematical models based on parallel vector processing are used in the crawling phase. While each process increased with the increase in operation and storage power, shrinkage in dimensions, reliability and the number of users, it decreased in prices (O'Brein, 1994).

Communication technologies are a concept that encompasses all technologies and technologies in communication. Therefore, communication technologies; transmission, telecommunication, communications, information publishing and printing. Communication technologies, telegraph, telephone, fax, telex, radio, television, satellite, interactive television, cable television, remote control, pager, GSM, transceiver, trunk radio, computer, modem, video player, video camera, video projector, amplifier It includes technologies such as CD-ROM, VCD, DVD, printer, printer, photocopy. 


\section{Information Age and Society}

Most of the developed and developing societies now exhibit the dominant qualities of neither agriculture nor industrial society. Nowadays, it is argued that people are confronted with the global information society, which is directly connected with the production, management and distribution of information resources and shaped by the global economy. In this context, only the information society that researches, produces and uses information technologies is considered an information society. Together with the information age, it is observed that the change has accelerated and reached a dizzying speed. It is necessary to invest in people, technology and education to adapt to the change and speed factor. The information economy is defined as network economy, digital economy, new economy and monopoly which affects the economic structure in which all economic activities are carried out in an economic system and information is integrated into the said activities.

Alvin Toffler (1992) emphasized that the first wave formed agriculture and the second wave formed the industrial societies and the transition to the information society described three as wave. The agricultural society, which is based on commodity goods that has no concrete knowledge, has left the money with concrete but symbolic values instead of the second wave of industrial revolution. The information that the third wave started to lead to, in the society, the transfer of information immediately continues to form the abstract money of the economy. According to Toffler, today's developed countries, which play an active role in the formation of second wave societies, have stepped into the third wave stage.

New materials produced based on technological innovations are used extensively and widely in the fields of electronics, information, communication, space, automotive and medicine. It is argued that the developments have created an information explosion and accelerated the transformation in the information age. In this context, technological innovations and developments empower individuals and create great opportunities for humanity (Öğüt, 2003).

Considering that the most prominent characteristics of the societies that are not in constant contact with the countries of superior technology are harmony and equilibrium, 
it can be argued that the countries which are in constant interaction with each other in the global information society should encourage advanced progress and should be structured in terms of dynamic equilibrium conditions rather than stable equilibrium.

Drucker has determined the existence of two basic issues in the transition from the industrial age to the information age. First; it is the change in the nature of the work, as abstract resources such as knowledge become more important than concrete sources. The second is doing and managing information work that requires new personal and organizational skills.

It is observed that the stability and search of the post-industrial society has been channelled to the production of rapid information, and thus, an increase in knowledge has been observed so far. It can be said that the great knowledge accumulated as a result of the increase of information leads to important changes in the life of the individual and the institution as well as in the community life by communicating, sharing and using. It is seen that the societies that are effective in the production and management of information and technology are oriented towards selling information. Organizational management in the information age has to constantly investigate and evaluate the needs of human resources and customers and these needs should be met. In the transition to the information age, the traditional management approach is becoming insufficient and it is becoming more and more depleted. In the information age, managers have to define and understand the interaction between technology, organization and human resources. Morover, learning habits must be developed in every institution and enterprises should be learning institutions.

The fast-growing technology, global competition, transnational and interactive culture that transcends regional and national traditions are the elements that shape the information age. The information age, which technology and knowledge give a new impetus, is progressing rapidly. This progress brings about social, economic and cultural change. In the information age, storage and transfer of knowledge through various methods are the strength and advantage of the people and institutions. The power of knowledge cannot be denied in order to make a strategically significant difference, to hold knowledge and to gain an advantage over opponents. However, to the extent that knowledge is available and acquired, the knowledge is valuable and meaningful. The value of knowledge cannot 
be mentioned for institutions that hold the most valuable knowledge but do not know how to use them (Goh, 2002). Therefore, institutions should be smart enough to use knowledge properly.

There are five basic features that differentiate the information age from previous periods. These features are (Senn, 1995);

- The information age consists of the rise of knowledge-based society.

- In the information age, businesses operate based on information technologies.

- Business processes in the information age turn into productivity gains.

- The success of the information age is measured by the effectiveness of the use of information technologies.

- In the information age, many products and services are intertwined with information technologies.

In a highly competitive environment of information age, in order to achieve competitive advantage, institutional information should be acquired better and faster and this information should be turned into a better and faster result than competitors (Powel, 2014). In today's world where the innovations in the information age are spreading, it is known that the majority of the societies live in the stages of agriculture, industry and advanced industrial society, but those who are dominant in the context of globalization are the countries that are in the information society stage.

The information society is a society that takes its dynamism from knowledge, educates the pioneer with the skills demanded by the society and the main production sector (Dura and Atik, 2002). This society, as an indicator of the standard of living, is defined by the quality of life as an indicator of services, health, education, recreation and art activities unlike the industrial society defined by the quantity of goods. The information society is a culture in which activities related to the collection, processing and dissemination of information have increased at an unprecedented speed. Post-industrial society is an information society in two senses: First, the source of all innovations in society is research and development. Secondly, both in terms of total production and employment, the main weight of the economy is knowledge.

The main characteristic of the information society is the rapid change. The reason why the transformation from the industrial society to the information society is much faster is 
due to the speed of development of new technologies and the high flexibility of people to adapt to this technology. Therefore, the information that is memorized by an extremely rigid discipline in the education process will become obsolete in a very short period, and the main thing is to encourage the creativity of individuals. However, standardization is seen as the biggest enemy of creativity today (Erkan, 1994).

\section{Social Networks}

With the development of technology, people communicate with each other and reach directly to information is one of the most important interaction tools that technology has given to people in the 21 st century. As a result of these developments, it has enabled the access to more secure and accurate resources by means of communication tools. Traditional media provided one-way communication and communicated only to people. It was difficult for people to respond or react to the news they had read, to check the accuracy and security of the information they acquired.

In addition, obstruction or manipulation of information was an easy task. However, the demand and the need to obtain information from accurate and reliable sources are increasing among individuals. This new stream, called the new media, is an abstract concept that defines the interactive communication power of the Internet and the tools that use this power are defined as social media tools "(Çildan et al., 2012).

Today's communication is transformed into dialogue by using social media tools and the information is spreading rapidly. As a result of this rapid expansion, many organizations can take immediate action. In Web 1.0, the first version of the Web, users were only in a passive role as a consumer. With the emergence of Web 2.0, people using social networks have made a significant contribution to the structuring of information. Further, people have communicated with each other and established cooperation environments with the help of computer networks.

Social networks are defined as a group of practices that increase group interaction in a web-based environment, common areas reserved for cooperation and social relations and provide information exchange (Bartlett-Bragg, 2006, p.3). As the definition indicates; interaction, cooperation, social relations and information exchange are the main features of social networks. Cheung and Lee (2010) stated that the main purpose of online social 
networks is social interaction and connection. Arnaboldi, Passarella, Tesconi, and Gaza (2011), on the one hand, have raised social networks from the center of self-centering to sociocentrism, and expressed individualized areas to improve their regulatory skills, as well as web-based applications that offer common areas of sharing to develop social interaction and collaboration skills. The use of social networks in terms of social media provides easy and ready-to-use environments for users. Social media contributes to keeping people's relationships in a network structure and keeping them alive.

Social media is telecommunication, technology, words, audio files and visuals through a structure where individuals share their experiences and stories. Web-based services are defined as social networks that allow the creation and sharing of open or closed profiles in a system where boundaries have been established and the connections listed in the profile of all the other users to whom the connection is established (Menteşe, 2013). Social networks; acknowledgments to the features that allow sharing of various content and profile information such as photos, videos and text, it attracts millions of users and therefore the use of social networks among internet users is growing day by day (Selwyn, 2007).

According to Sayımer (2008), social media is a common term for online tools and websites that interact with users by allowing them to share information, thoughts, interests and information. The world is a site that gives information about the popularity of the social networking site that has a whole According to Alexa data, compared with all other sites on Facebook is the second most popular site in the world and Turkey (Alexa, 2013).

It is seen that social networks reach to wide user communities in parallel with the features offered to users and researchers in different disciplines such as psychology, education, management, marketing, sociology, anthropology and medicine have attracted their attention for different reasons. The use of social networks, which are used extensively throughout the world, differs from person to person. Boyd and Ellison (2008) features of social networks:

- create a publicly accessible or semi-open profile within a limited system, - add and specify a list of other users, who have a link to them, 
- web-based services that allow you to view and act on the connection lists created by others and created by others on the system.

Communication, which started with technological developments, has now become a socialization platform. The first social networks, rather than sharing, aimed at more acquaintance and messaging. With the launch of Facebook in 2004 and Twitter in 2006, social networks have formed and formed online groups that provide not only the introduction and messaging, but also the organization of ideas and knowledge, and groups around beliefs and beliefs.

Media types such as audio files, images, video clips, web addresses are defined as social content. Social content can be used, shared or shared by social networks, and can be produced or shared in social networks. With the development of technology, applications such as Youtube, Slideshare, blog, twitter and wiki have been created to support the communities that provide collaboration, communication and content production and bring people like Facebook together.

In recent years, social networking in the field of educational technologies was observed that there is an increase in studies for determining the usage of technologies and which usage activities are preferred more frequently by students (Mazman and Usluel, 2010). The application of social networks to the broad masses of people of all ages requires that what can be done for life-long learning, not only in schools. In this context, it can be argued that the general purpose of social networking sites will guide the researchers who want to use these sites as informal as well as formal.

Social networks provide opportunities such as community building, personal expression and collaboration (Gülbahar et al., 2010). The uses of social networking sites differ. While socializing is the primary goal, it is possible to find information about relatives, friends and their personal lives, to learn and share daily news and events, to establish relationships, and to be in constant communication with colleagues from the same profession.

Because of their privacy features and user-friendliness, social networks address many users. Social networks, which have the capacity to create people's environment, prevent people from communicating with people they do not want, as well as being able to follow the group with people with similar tastes and members of the desired group. Social networks, defined as the sub-group of social software, have a special place among users. 
Social networks such as Facebook, which people of all ages use frequently, have an incredible growth power. Information about the use of social networking Gürsakal (2009) is summarized as follows:

- Participation: Participation and feedback are provided because users constantly produce content,

- Clearance: There is no obstacle in the use and access of the content,

- Mutual speech: Two-way communication,

- Community: Effective communication is ensured with groups of people interested in the same subject,

- Connectivity: Allows communication with other sources, contacts and sites.

Social networks across the social media have been defined by the Internet communities Pempek, Yermolayeva and Calvert (2008), which allow users to share profile information, send private or online messages, and share photos and videos with other users. In addition, social networking sites have been described in the literature with definitions such as social network (Çetin, 2009), informal learning environment (Mitchell, 2009), and the main purpose of social networking site participants is the desire to reach people who have not been able to meet for a long time. (Boyd and Ellison, 2008). The definition of the social networks representing individuals, organizations and enterprises and their relations with each other reveals that social networks can not only consist of family, friends and common interest groups, but also professional connections such as colleagues and employees.

\section{Conclusions}

In terms of management science, the two most important concepts of the current period are information and technology. Information is the most important factor of production and the indispensable element of the enterprises and enterprises are as important as capital. For this reason, the information age, society, information society and people are called knowledge workers. In this period, knowledge has become the source of wealth. Knowledge management is also an important management area that treats mental capital as a manageable value. In this process, enterprise dynamics, management models and technology are considered as important tools in information management. The tools in question aim to obtain data and information from an enterprise, to develop the information 
obtained, to transfer, transfer and use of these to individuals who have certain duties. Due to the nature of knowledge, today's most advanced information can lose its importance tomorrow. Therefore, knowledge management should not be considered as a static and limited process but as a matter of strategic importance for businesses.

Knowledge management covers all kinds of information sources from the database to the web sites, company employees and business partners. In terms of structure, information management expands the meaning of this information and shapes it. The company increases the value of the company by helping employees improve their creativity and adapt to changes. Because, while calculating the market values of companies, values such as ability to adapt to change, management qualities and ability to reach new markets have begun to be taken into account in addition to tangible assets.

Each company manages the information. The difference between success and failure in today's competitive environment is how well the company can manage its knowledge in the market. Effective information management aims to optimize the decision making process by delivering the right information to the right person at the right time. Changing market conditions make information management indispensable. Tools such as Activity Based Management and Process Management for the management and measurement of tangible assets are no longer a differentiating element for contemporary organizations and have become a necessity. Companies capture customer satisfaction with knowledge management. Knowledge management is a strategic issue for organizations. The information management strategy is also a reflection of the organization's competitive strategy. How the value is created for the customers and the contribution of the employees to this value, how the value of the economic model is supported by knowledge management strategies.

Information technology is an integral part of daily human life. Information is an important business and human resource, while it is considered, stored, and communicates the technology that provides communication. People are affected by the developments in information technology. There are huge changes in data processing, office automation, 
communication and other electronic technologies used in the management of business and development of strategies in large and small enterprises. With the new information technologies developed, managers make more accurate decisions and spend most of their time on numbers rather than on numbers.

Many of the traditional firms are still unaware of the value and use of information they have. Yet success is now in direct proportion to the quality of knowledge. Most simply, for product development; it is necessary to be aware of both new technologies and new sciences, both consumer needs and marketing of the product, and moreover, these must be used correctly. The fact that the market areas are growing more and more open to competition and that the number of innovations increase day by day, making the information evolve and consuming more quickly than ever before is a necessity.

In the information age, the only factor that increases the market value of enterprises and provides a competitive advantage is all values that are the extension of knowledge and knowledge. The only reliable source of continuous competitive advantage in an economic order dominated by uncertainty is knowledge itself. When the markets change, when the technological developments increase, when the competitors increase and the products become obsolete in a short period of time, the enterprises will be consistently creating new knowledge, spreading this information widely throughout the organization and rapidly using in new technologies and products.

Individuals use information technologies for different purposes. Information has become a part of our lives with the help of different systems and social networks we are a member of, and tools such as mobile phones and laptops are used to connect to these networks. Thanks to the features of the mobile phone, data is easily converted to information and stored. As a result of the developments, institutions and organizations are making more radical decisions under the guarantee of continuous learning, knowledge formation and, accordingly, making decisions, and acting safer within the organizations. Since e-mails, which provide communication in the fastest way, are information storage networks, information technologies are provided to organizations by using this information. The 
success of knowledge management depends on the interpretation of the technology and information used by the leader.

In organizational correspondence, data obtained with the help of information technologies REICE | 439 are collected, classified, recorded and processed in a way to be converted into information and used in decision processes. Information and communication technologies that provide communication in management are developing rapidly. Video-tape recorders, telesecretarial devices, closed-circuit television systems, fax machines and machines provide new communication flexibility in management. The most important benefit of communication technology is that it provides great convenience to written communication. The advantages of communication technologies for written communication are: Reduce costs and increase productivity. Reduces repetition, simplifies data entry and reduces time consumption. They reduce the use of physical space required by paper use. They provide efficiency in document management. They considerably reduce the costs of jobs in offices.

\section{References}

Ackoff, R.L. (1996), "On learning and the systems that facilitate it", Center for Quality of Management Journal, Vol. 5 No. 2, pp. 27-35.

Ackoff, R. L. 1989. From data to wisdom. Journal of Applied Systems Analysis, 16, 3-9

Afshari, A., Mojahed, M. ve Yusuff, R.M. (2010). Simple Additive Weighting Approach to Personnel Selection Problem, International Journal of Innovation, Management and Technology, Cilt: 1, Sayı: 5, s.511-515.

Ahani,M., Bahrami, H.R. ve Shariflu, B. (2013). Determining the Dimension of Knowledge Management Implementation by Utilizing a Fuzzy TOPSIS Method, International Jurnal of Business Administration, Cilt: 4, Sayı: 1, s.113-123 
Alavi, M. and Leidner, D. (1999), "Knowledge management systems: issues, challenges and benefits", Communications of the Association for Information Systems, Vol. 1 No. 7 , pp. 2-36.

Alavi, M. and Leidner, D.E. (2001), "Review: knowledge management and knowledge REICE | 440 management systems: conceptual foundations and research issues", MIS Quarterly, Vol. 25 No. 1, pp. 107-36.

Allen, J. P. 2000. Information systems as technological innovation. Information Technology \& People, 13, 210-221.

Allee, V. (1997). The Knowledge Evolution: Expanding Organizational Intelligence, Butterworth-Heinemann.

Albers, J. A. (2009, Mart). A Practical Approach To Implementing Knowledge Management, Journal of Knowledge Management Practice, Cilt: 10, Sayı: 1.

Arnaboldi, V., Passarella, A., Tesconi, M., \& Gazze, D. (2011). Towards a Characterization of Egocentric Networks in Online Social Networks. In R. Meersman, T. Dillion \& P.Herrero (Eds.), On the Move to Meaningful Internet Systems: Otm 2011 Workshops (Vol. 7046, pp. 524-533). Berlin: Springer-Verlag Berlin.

Armstrong Employee Reward, (1996), London: Institute of Personnel and Development (IPD) House.

Aurum, A., Daneshgar, F. and Ward, J. (2007). Investigating Knowledge Management Practices in Software Development Organisations - An Australian Experience, Elsevier Information and Software Technology.

Awad, E. M. \& Ghaziri, H. M. 2004. Knowledge Management, Upper Saddle River, NJ, Pearson Education International. 
Barnatt, Christopher, (1996) Management Strategy and Information Technology: Text and Reading, First Edition, International Thomson Business Press, London.

Barutçugil, I., "Bilgi Yönetimi”, İstanbul: Kariyer Yayınları, (2002).

Beijerse, R.P. uit. (1999). Questions in Knowledge Management: Defining And Conceptualising a Phenomenon, Journal of Knowledge Management, Cilt: 3, Sayı: 2, s. 94-109.

Bergeron, B. (2003). Essentials of Knowledge Management, New Jersey: Wiley.

Beynon-Davies, P. (2009). The 'language' of informatics: The nature of information systems.International Journal of Information Management, 29, 92-103.

Beynon-Davies, P. (2009). Neolithic informatics: The nature of information. International Journal of Information Management, 29, 3-14.

Beynon-Davies, P. (2009). Significant threads: The nature of data. International Journal of Information Management, 29, 170-188.

Beynon-Davies, P. 2011. In-formation on the prairie: Signs, patterns, systems and prairie dogs. International Journal of Information Management, 31, 307-316.

Bhatt, G.D. (2001). Knowledge Management in Organizations: Examining the Interaction Between Technologies, Techniques, and People, Journal of Knowledge Management, Cilt: 5, Sayı: 1, s. 68-75.

Bierly, P. E., Kessler, E. H. \& Christensen, E. W. 2000. Organizational learning, knowledge and wisdom. Journal of Organizational Change Management, 13, 595618. 
Bingöl, D.,(1998), “İnsan Kaynakları Yönetimi”, Beta Basım Yayın Dağııım, İstanbul.

Boisot, M. \& Canals, A. (2004). Data, information and knowledge: have we got it right? Journal of Evolutionary Economics, 14, 43-67.

Bocij, P., Chaffey, D., Greasley, A. \& Hickie, S. 2003. Business Information Systems: Technology, Development and Management for the e-Business, Harlow, FT Prentice Hall.

Boddy, D., Boonstra, A. \& Kennedy, G. 2005. Managing Information Systems: an Organizational Perspective, Harlow, FT Prentice Hall.

Bonds-Raacke, J., \& Raacke, J. (2010). MySpace and Facebook: Identifying Dimensions of Uses and Gratifications for Friend Networking Sites. Individual Differences Research,8(1), 27-33.

Bourdreau, A. and Couillard, G. (1999), "System integration and knowledge management", Information Systems Management, Vol. 16 No. 4, pp. 24-32.

Boyd, D. M. ve Elison, N. B. (2008). Social network sites: definition, history and scholarship. Journal of Computer Mediated Communication, 13(1).

Buckland, Michael. (1991). Information and information systems. New York: Greenwood Press.

Byars, Lloyd L.; (1992) "Concepts of Strategic Management, 3rd Edition”, Harper Collins Publishers, New York.

Cevizli, A. (2010), 'Bilgi Felsefesi', Say Yayınları, İstanbul.

Chaffey, D. \& Wood, S. 2005. Business Information Management: Improving Performance Using Information Systems, Harlow, FT Prentice Hall. 
Chen, M., Ebert, D., Hagen, H., Laramee, R. S., Liere, R. v., Ma, K.-L., Ribarsky, W., Scheuermann, G. \& Silver, D. 2009. Data, Information, and Knowledge in Visualization. IEEE Computer Graphics and Applications, 29, 12-19.

Cheung, C. M. K., \& Lee, M. K. O. (2010). A theoretical model of intentional social action in online social networks. Decision Support Systems, 49(1), 24-30.

Cheung, C. M., Lee, M. K., \& Lee, Z. W. (2013). Understanding the Continuance Intention of Knowledge Sharing in Online Communities of Practice Through the PostKnowledge-Sharing Evaluation Processes. Journal Of The American Society for Information Science and Technology, 64(7), pp. 1357-1374.

Chiu CM, Hsu MH, Wang ET (2006) Understanding knowledge sharing in virtual communities: An integration of social capital and social cognitive theories", Decision Support Systems, 42(3): 1872-1888.

Churchman, C.W. (1972), The Design of Inquiring Systems: Basic Concepts of Systems and Organizations, Bencis Books, New York, NY.

Claver, E., Llopis, J., Gonzalez, M. R. \& Gasco, J. L. (2001). The performance of information systems through organizational culture. Information Technology \& People, 14, 247-260.

Darroch, J., (2005), “Knowledge management, innovation and firm performance”, Journal of Knowledge Management, 9 (3).

Davenport, T. and Prusak, L. (1998), Working Knowledge, Harvard Business School Press, Boston, MA.

Davenport T. H.,- Laurence P., “İş Dünyasında Bilgi Yönetimi” (Çev. Günay). İstanbul: Rota Yayınları, (2001). 
Drucker, P.E. (1995), “The post capitalist executive”, in Drucker, P.E. (Ed.), Management in a Time of Great Change, Penguin Press, New York, NY.

Dura, Cihan ve Atik, Hayriye, (2002), "Bilgi Toplumu, Bilgi Ekonomisi ve Türkiye", Literatür Yayıncılık, 1. Basım, İstanbul.

Falkenberg, E. D., Hesse, W., Lindgreen, P., Nilsson, B. E., Oei, J. L. H., Rolland, C., Stamper, R. K., Assche, F. J. M. V., Verrijn-Stuart, A. A. \& Voss, K. 1998. A Framework of Information System Concepts: The FRISCO Report, Netherlands, Department of Computer Science, University of Leiden.

Firestone, J.. (2005), “Has Knowledge Management Been Done?", Bradford, , UK: Emerald Group Publishing Limited.

Fricke, M. 2009. The knowledge pyramid: a critique of the DIKW hierarchy. Journal of Information Science, 35, 131-142.

Galliers, R. \& Newell, S. 2001. Back to the Future: From Knowledge Management to Data Management. Proceedings of ECIS. Bled, Slovenia.

Gray, P. H. \& Meister, D. B. (2003). Introduction: fragmentation and integration in knowledge management research. Information Technology \& People, 16, 259-265.

Groff, T. R. \& Jones, T. P. (2003). Introduction to Knowledge Management: KM in Business, Amsterdam, Butterworth Heinemann.

Gunasekaran, Angappa and McGaughey, Ronald, (2002), "Information Technology/Information Systems in 21st Century Manufacturing", International Journal of Production Economics, Vol: 75. 
Hansen, M.T., Nohria, N. and Kierney, T. (1999), "What's your strategy for managing knowledge?", Harvard Business Review, March-April, pp. 109-22.

Hertog, J. Friso Den ve Edward Huizenga, (2000), "The Knowledge Enterprise: Implementation of Intelligent Business Strategies", London, Imperial College Pres, Vol.2.

Jason, L. A., Reichler, A., King, C., Madsen, D., Camacho, J. \& Marchese, W. 2001. The Measurement of Wisdom: A Preliminary Effort. Journal of Community Psychology, 29, 585-98.

Karasar, N., (1999) Bilimsel araştırma yöntemi. 9. Basım, Ankara: Nobel Yayın Dağıtım.

Kantner, J. (1999), "Knowledge management, practically speaking”, Information Systems Management, Fall, pp. 7-15.

Lam, W. and Chua, A., (2005), "The mismanagement of knowledge management", Aslib Proceedings: New Information Perspectives, 57 (5),424-433.

Li, M. and Gao, F. (2003), "Why Nonaka highlights tacit knowledge: a critical review", Journal of Knowledge Management, Vol. 7 No. 4, pp. 6-14.

McElroy, M.W. (2000), "Integrating complexity theory, knowledge management, and organizational learning", Journal of Knowledge Management, Vol. 4 No. 1, pp. 195203.

Machlup, Fritz (1980). Knowledge and knowledge production. Princeton, NJ: Princeton University Press. 
Markus, M.L. (2001), "Toward a theory of knowledge reuse: types of knowledge reuse situations and factors in reuse success", Journal of Management Information Systems, Vol. 18 No. 1, pp. 57-93.

Marr, B., Gupta, O., Pike, S. and Roos, G., ,(2003) "Intellectual capital and knowledge management effectiveness", Management Decision, 41 (8), 771- 781.

Martini, A. and Pellegrini, L.. (2005), Barriers and levers towards, "Knowledge management configurations A case study-based approach", Journal of Manufacturing Technology Management, 16 (6).

McDermott, R. (1999). Why Information Technology Inspired But Cannot Deliver Knowledge Managennent. California Management Journal, 41, 103-117.

Mutsaers Jan Ernest, Van Der Han Zee and Henrick Gierts, (1998), "The Evolution of Information Technology", Information Management \& Computer Security,Vol:6, No: 3.

Nonaka, I. (1994), "A dynamic theory of organizational knowledge creation", Organization Science, Vol. 5 No. 1, pp. 14-17.

Nonaka, I., \& Konno, N. (1998). The concept of 'Ba': Building a foundation for knowledge creation. California Management Review, 40(3), pp. 40-54.

Öğüt, A., (2001): Bilgi çağında yönetim, Ankara: Nobel Yayın Dağıtım.

Pawar Kulwant S. and Driva Helen, (2000) "Elektronic Trading in Supply Chain: A Holistic Implementation Framework", Logistic Information Management, Vol:13, No: 1

Pozo, M., Manuel, C., González-Arangüena, E., Owen, G. (2011). Centrality in directed social networks: A game theoretic approach. Social Networks, 33, 91-200. 
Putnam R (1993) Making Democracy Work, Princeton University Press, Princeton, NJ.

Putnam R, Robert D (1993) The prosperous community: Social capital and public life. American Prospect, 4 (13): .35-42.

Reynolds, J. (2010). "Dominos Credits Social Media Sales Growth, Marketing Magazine.

Riege A (2006) Three-dozen knowledge-sharing barriers managers must consider, Emerald Group Publishing Limited, Journal of Knowledge Management, 9(3): 1835.

Roger Bryne, (2001), “Employees: Capital or Commodity?”, The Learning Organization, C.8,S. ,s.44-50.

Roos, J., Roos, G., Dragonetti, N.C. and Edvinsson, L. (1997), Intellectual Capital: Navigating in the New Business Landscape, Macmillan, Basingtoke.

Rowley, Jennifer (2007). The wisdom hierarchy: Representations of the DIKW hierarchy. Journal of Information Science 33: 163-180.

Sağsan M (2006) Bilgi yönetimi bakış açısından bilgi süreçleri ve bir model önerisi. ÜNAK'06: Bilimsel iletişim ve bilgi yönetimi sempozyumu: 27-44.

Sağsan M., (2007), Uygulamadan Disipline Bilgi Yönetimi ve Bir Alan Çalışması, Amme. İdaresi Dergisi, Sayı: 4.

Sayımer, İ. (2009). Sanal Ortamda Stratejik Halkla İlişkiler Yönetimi. İstanbul: Beta Yayınları.

Senn, James A., (1995) "Information Tecnology in Business", Prentice Hall Int, New Jersey. 
Schultheis, Robert and Sumner, Marry, (1995), Management Information Systems: The Manager's View, Irwin, Chicago.

Smith P., (2002) "A Performance based Approach to Knowledge Management", Journal of Knowledge Management Practice.

Stewart T.A., (1997) "Entelektüel Sermaye: Kuruluşların Yeni Zenginliği”, (Çeviren: Nurettin Elhüseyni). İstanbul: MESS.

Tuomi, I. (1999), "Data is more than knowledge: implications of the reversed knowledge hierarchy for knowledge management and organizational memory", Journal of Management Information Systems, Vol. 16 No. 3, pp. 103-17.

Tsui, E. (2003), "Tracking the role and evolution of commercial knowledge management software", in Holsapple, C.W. (Ed.), Handbook on Knowledge Management Volume 2: Knowledge Directions, Springer, Berlin, pp. 5-27.

Vail, E.F. (1999), "Knowledge mapping: getting started with knowledge management", Information Systems Management, Vol. 16 No. 4, pp. 16-23.

Wasko, M. M., \& Faraj, S. (2005). Why Should I Share? Examining Social Capital and Knowledge Contribution in ElectronicNetworks of Practice. MIS Quarterly, 29(1), pp. 35-57.

Wniner, S. R. (2009). New communications approaches in marketing: Issues and Research Directions. Journal of Interactive Marketing, 23(2), 108-117.

Zaim H., (2005) "Bilginin Artan Önemi ve Bilgi Yönetimi”, İşaret Yayınları:106, İstanbul.

Zins, Chaim (2007). Conceptual approaches for defining data, information, and knowledge. Journal of the American Society for Information Science and Technology 58: 479-493. 